\title{
Ege Üniversitesi Hastanesi'ne başvuran santral sinir sistemi enfeksiyonu olgularında saptanan viral etkenler
}

\author{
Viral agents in patients with central nervous infections admitted to Ege University \\ Hospital

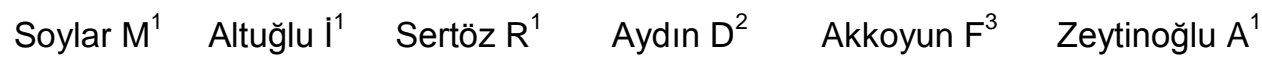 \\ ${ }^{1}$ Ege Üniversitesi Tıp Fakültesi, Tıbbi Mikrobiyoloji Anabilim Dalı, İzmir, Türkiye \\ ${ }^{2}$ Ege Üniversitesi Tıp Fakültesi, Çocuk Sağlığı ve Hastalıkları Anabilim Dalı, İzmir, Türkiye \\ ${ }^{3}$ Ege Üniversitesi Tıp Fakültesi, Nöroloji Anabilim Dalı, İzmir, Türkiye
}

\section{Özet}

Amaç: Santral sinir sistemi enfeksiyonları, hızlı ilerleme potansiyeli ve kalıcı nörolojik hasar olasılığı nedeniyle çoğunlukla acil tanı ve tedavi yaklaşımı gerektirir. Bu çalışmada Ege Üniversitesi Tıp Fakültesi Tıbbi Mikrobiyoloji Anabilim Dalı'na viral santral sinir sistemi enfeksiyonu ön tanısı düşünülerek gönderilen beyin omurilik sıvıSı (BOS) örneklerinde nükleik asit testleri ile saptanan viral etkenlerin değerlendirilmesi amaçlandı.

Gereç ve Yöntem: Ege Üniversitesi Tıp Fakültesi Tıbbi Mikrobiyoloji Anabilim Dalı Laboratuvarı'na, Ocak 2012Aralık 2012 tarihleri arasında viral santral sinir sistemi enfeksiyonu ön tanısı düşünülerek nükleik asit testleri yapılması amacı ile gönderilen toplam 289 BOS örneğinin sonucu retrospektif olarak değerlendirildi. Toplam 198 BOS örneği HSV DNA (LightCycler HSV 1/2 Qual Kit, Roche, Almanya), 46 örnek CMV DNA (Fluorion CMV QNP 3.0 Real-Time PCR, l̇ontek, Türkiye), 20 örnek EBV DNA (LightMix Kit Epstein-Barr virus, TIB MOLBIOL, Almanya), 25 örnek Enterovirus RNA (GeneXpert Xpert EV, Cepheid, ABD) varlığı açısından araştırıldı.

Bulgular: Hastaların 153'ü kadın, 136'si erkekti ve yaşları 0 - 88 arasında değişmekte idi (median yaş 39). HSV DNA incelemesi yapılan 198 olgunun ikisinde (\%1) pozitiflik, CMV DNA incelemesi yapılan 46 olgunun birinde (\%2) pozitiflik, EBV DNA incelemesi yapılan 20 olgunun üçünde (\%15) pozitiflik ve Enterovirus RNA incelemesi yapılan 25 olgunun birinde (\%4) pozitiflik saptandı.

Sonuç: SSS viral enfeksiyonları klinikte nadir görülmemekle birlikte insidansları net olarak belirlenmemiştir. Mortalitesinin yüksek olması, hızıı ilerlemesi ve sekel bırakma olasılığının fazla olması nedeni ile önemli bir hastalık grubudur. Birçok olgunun etiyolojisi bilinmemekle birlikte özellikle moleküler tekniklerin gelişimi ile viral etkenlerin saptanmasında artış olmuştur.

Anahtar Sözcükler: Santral sinir sistemi enfeksiyonları, viral ensefalit, viral menenjit.

\section{Summary}

Aim: Central Nervous system (CNS) infections require a rapid diagnosis and treatment approach due to their potential of rapid progression and the possibility of permanent neurological damage. In this study, viral agents detected by nucleic acid tests in the cerebrospinal fluid samples of patients with a suspicion of viral CNS infection were sent to Medical Microbiology Laboratory of Ege University Hospital and evaluated.

Materials and Methods: A total number of 289 CSF samples submitted to Medical Microbiology Laboratory from January 2012 to December 2012 for viral nucleic acid testing were evaluated retrospectively. One hundred ninety eight CSF samples were tested for HSV DNA (HSV LightCycler 1/2 Qual Kit, Roche, Germany), 46 samples for CMV DNA (CMV Fluorion QNP 3.0 Real-Time PCR, lontek, Turkey), 20 samples for EBV DNA (Lightmix Kit Epstein-Barr virus, TIB MOLBIOL, Germany) and 25 samples for Enterovirus RNA (GeneXpert Xpert EV, Cepheid, USA).

Results: One hundred fifty three patients were females and 136 were males, ages ranging from 0 to 88 (median age 39) years. HSV DNA was detected by nucleic acid testing in two of the 198 patients (1\%), CMV DNA in one of the 46 patients (2\%), EBV DNA three of the 20 patients (15\%) and enterovirus RNA in one of the 25 patients (4\%).

Yazışma Adresi: Muhammed SOYLAR

Ege Üniversitesi Tıp Fakültesi, Tıbbi Mikrobiyoloji Anabilim Dalı, İzmir, Türkiye

Makalenin Geliş Tarihi: 04.10.2013 Kabul Tarihi: 11.11.2013 
Conclusion: Even though CNS infections are not rare, the incidence is not clearly established. Due to high mortality rate and potential of neurological damage, they are extremely important. Even though the etiology is unknown in many cases, the development of molecular techniques has increased the detection rate of viral agents.

Key Words: Central nervous system infections, viral encephalitis, viral meningitis.

\section{Giriş}

Virüs, bakteri, mantar ve parazitler santral sinir sisteminde enfeksiyona neden olabilir. Santral sinir sistemi enfeksiyonlarının klinik seyri enfeksiyonun tipine göre akut, subakut ya da kronik olabildiği gibi kendini sınırlayan enfeksiyonlardan hızla ilerleyip ölümcül olanlara dek farklııklar gösterebilir. Hızlı ilerleme potansiyeli ve kalıcı nörolojik hasar olasılığı nedeniyle çoğunlukla acil tanı ve tedavi yaklaşımı gereklidir (1). Santral sinir sistemi enfeksiyonları; menenjit, ensefalit ve ensefalomiyelitten beyin apselerine, subdural ampiyem, epidural apse, nörit ve intrakraniyal flebitlere kadar geniş bir klinik dağılım gösterir (2).

Epidemiyolojik ve mikrobiyolojik araştırmalar akut aseptik menenjitte etken olarak \%70'e varan oranlarda virüsleri göstermektedir (3). Enterovirüsler viral menenjitlerin en sık nedenidir ve yaklaşık \%80-95'inden sorumludur $(4,5)$. Süt çocukları ve küçük çocuklar en riskli gruptur (6). Kabakulak, aşısız bir toplumda, aseptik menenjit ve ensefalitin önde gelen nedenlerindendir, ancak aşı uygulanan toplumlarda çok nadirdir $(7,8)$. Herpes virüs ailesindeki herpes simpleks virüsü (HSV) tip 1 ve tip 2, Epstein-Barr virüsü (EBV), varisella zoster virüsü (VZV), sitomegalovirüs (CMV), insan herpes virüsü 6 (HHV6) nedenli enfeksiyonlar ile çeşitli nörolojik sorunlar görülebilir (9). Herpes simpleks ensefaliti sporadik fatal ensefalitin önde gelen nedenidir (10). Arbovirüs enfeksiyonlarında ensefalit en sık görülen nörolojik tutulumdur. Arbovirüsler, Kuzey Amerika'daki aseptik menenjit olgularının \%5'inden sorumludur (7). Insan immun yetmezlik virüsü (HIV) enfeksiyonunda menenjit ya da meningoensefalit görülebilir. HIV beyin zarlarını erken dönemde tutabilir ve ilk enfeksiyon sonrasında santral sinir sisteminde kalıcı olabilir (3). Kızamık ve adenovirüs özellikle immun yetmezlikli hastalarda ensefalit ve meningoensefalitin bilinen etkenleridir. Parainfluenza tip 3 (11), parvovirüs B19 (12), influenza, rotavirüs, rinovirüs ve koronavirüs (7) enfeksiyonları seyrinde nadiren de olsa aseptik menenjit görülebilir.

Santral sinir sistemi enfeksiyonları tanısında özgül mikrobiyolojik tanı testleri arasında; hücre kültürü, viral nükleik asitlerin saptanması, beyin omurilik SIVISI (BOS) antikor ve antijen tayini bulunmaktadır. BT, MR, EEG gibi görüntüleme yöntemleri de kullanılabilir $(13,14)$.

Bu çalışmada Ege Üniversitesi Tıp Fakültesi Tıbbi Mikrobiyoloji Anabilim Dalı'na viral santral sinir sistemi enfeksiyonu ön tanısı düşünülerek gönderilen BOS örneklerinde nükleik asit testleri ile saptanan viral etkenlerin değerlendirilmesi amaçlandı.

\section{Gereç ve Yöntem}

Ege Üniversitesi Tıbbi Mikrobiyoloji Anabilim Dalı Laboratuvarı'na, Ocak 2012-Aralık 2012 tarihleri arasında viral santral sinir sistemi enfeksiyonu ön tanısı düşünülerek nükleik asit testleri yapılması amacı ile gönderilen toplam 289 BOS örneğinin sonucu retrospektif olarak değerlendirildi. Toplam 198 BOS örneği HSV DNA (LightCycler HSV $1 / 2$ Qual Kit, Roche, Almanya), 46 örnek CMV DNA (Fluorion CMV QNP 3.0 Real-Time PCR, lontek, Türkiye), 20 örnek EBV DNA (LightMix Kit Epstein-Barr virus, TIB MOLBIOL, Almanya), 25 örnek Enterovirus RNA (GeneXpert Enterovirus assay, Cepheid, ABD) varlığı açısından araştırıldı.

\section{Bulgular}

Hastaların 153'ü kadın, 136'si erkekti ve yaşları $0-88$ arasında (median yaş 39) değişmekte idi. Farklı viral etkenler açısından incelenen hastaların yaş, cinsiyet ve pozitiflik oranları Tablo-1'de gösterilmiştir.

Tablo-1. Yaş Aralıkları, Ortalama ve Median, Cinsiyetleri ve Pozitiflik Oranları.

\begin{tabular}{ccccccccc}
\hline & Pozitif (\%) & Negatif (\%) & Erkek & Kadın & $\begin{array}{c}\text { Ortalama } \\
\text { yaş }\end{array}$ & Median yaş & $\begin{array}{c}\text { Yaş } \\
\text { aralığı }\end{array}$ & $\begin{array}{c}\text { Toplam } \\
\text { sayı }\end{array}$ \\
\hline HSV & $2(\% 1)$ & $196(\% 99)$ & 98 & 100 & 43.4 & 42.5 & $0-88$ & 198 \\
\hline CMV & $1(\% 2)$ & $45(\% 98)$ & 20 & 26 & 36.5 & 34 & $3-75$ & 46 \\
\hline $\begin{array}{c}\text { ENTERO } \\
\text { VIRUS }\end{array}$ & $1(\% 4)$ & $24(\% 96)$ & 11 & 14 & 25.5 & 24 & $0-71$ & 25 \\
\hline EBV & $3(\% 15)$ & $17(\% 85)$ & 7 & 13 & 24.3 & 14 & $0-75$ & 20 \\
\hline $\begin{array}{c}\text { Toplam } \\
\text { (Yüzde) }\end{array}$ & $7(\% 2)$ & $282(\% 98)$ & 136 & 153 & & & & 289 \\
\hline
\end{tabular}


Viral etken açısından pozitif olarak saptanan yedi olgunun öyküleri kısaca aşağıda özetlenmiştir.

\section{HSV-1 DNA pozitifliği saptanan hastalar}

Olgu-1. 39 yaşında kadın hasta ateş yüksekliği, unutkanlık ve nöbet geçirme yakınmaları olması üzerine akut ensefalit ön tanısı ile yatırıldı. BOS biyokimyasında glukoz: $47 \mathrm{mg} / \mathrm{dL}$ (45-75 mg/dL), protein: $115 \mathrm{mg} / \mathrm{dL}$ (15$45 \mathrm{mg} / \mathrm{dL}$ ) olarak saptandı. Kranial MR incelemesinde bilateral temporal lobda sağ lobda daha belirgin tutulum gösteren ensefalit ile uyumlu görünüm mevcuttu. BOS'ta HSV-1 DNA PCR (+) saptanan olgu tedavi ile taburcu edildi.

Olgu-2. 68 yaşında erkek hasta bacaklarda güçsüzlük, idrar yapamama ve döküntü yakınmaları olması üzerine myelit ön tanısı ile yatırıldı. Yapılan MR tetkikinde servikal ve torakal bölgede uzun segment boyunca myelit ile uyumlu lezyon görüldü. BOS'ta HSV-1 DNA PCR (+) ve BOS biyokimyasında protein: $129 \mathrm{mg} / \mathrm{dl}$ (15$45 \mathrm{mg} / \mathrm{dl}$ ) saptanan olgu tedavisi devam etmekte iken kendi isteğiyle hastaneden ayrıldı.

\section{DNA pozitifliği saptanan olgu}

Charcot-Marie-Tooth tanılı 63 yaşındaki erkek hastanın solunum sıkıntısı ve bilinç bulanıklığı yakınmaları olması üzerine yatışı yapıldı. Yapılan tetkiklerinde CMV DNA (+) saptanan olgu kardiyak arrest gelişmesi sonucu ex oldu.

\section{Enterovirüs RNA pozitifliği saptanan olgu}

Ateş yüksekliği yakınması olan 2 aylık kız hasta akut menenjit ön tanısı ile yatırıldı. BOS mikroskobisinde bol eritrosit ve 40 lökosit $/ \mathrm{mm}^{3}$ görüldü. BOS biyokimyasında glukoz: $39 \mathrm{mg} / \mathrm{dl}(45-75 \mathrm{mg} / \mathrm{dl})$ ve protein: $0.67 \mathrm{~g} / \mathrm{L}$ (0.16-0.33 g/L) saptandı. BOS viral incelemesinde Enterovirus RNA (+) olarak saptandı. Şifa ile taburcu edildi.

\section{EBV DNA pozitifliği saptanan olgular}

Olgu-1. Sekiz yaşında kız hasta ateş ve nöbet geçirme yakınmaları olması üzerine menenjit ön tanısı ile yatırıldı. Fizik muayenede ense sertliği (+) olan hastanın BOS mikroskobisinde 800 lökosit/mm3 görüldü. BOS'ta EBV DNA (+) olarak saptanan hastanın eş zamanlı kan örneği olmamakla beraber iki hafta sonra yollanan kan örneğinde serum serolojisinde anti-VCA $\operatorname{lgM}(+)$, antiVCA IgG (+) ve anti-EBNA (+) olarak saptandı. EBV ilişkili aseptik menenjit tanısı ile tedavi edilerek taburcu edildi.

Olgu-2. Üç yaşında ALL tanılı kız hastada uykuya eğilim ve ateş yüksekliği yakınmalarının olması üzerine yapılan kraniyal MR tetkikinde yaygın serebral infarkt ve ensefalit ile uyumlu görünüm saptandı. Yapılan BOS incelemesinde EBV DNA (+) olarak saptandı. Olgu tedavi ile taburcu edildi.

Olgu-3. 56 yaşında kadın hasta yürüme güçlüğü, bilinç bulanıklığı ve görsel hallüsinasyon yakınmaları ile nöroloji servisine yatırıldı. Yapılan kraniyal MR tetkikinde serebral ve serebellar hemisferde yaygın lezyonlar görüldü. Hastanın BOS biyokimyasal incelemesinde BOS proteini: $86 \mathrm{mg} / \mathrm{dl}$ (15-45 mg/dl), BOS glukozu: 92 $\mathrm{mg} / \mathrm{dl}$ (45-75 mg/dl) ve eş zamanlı kan şekeri: $168 \mathrm{mg} / \mathrm{dl}$ (60-110 mg/dl) olarak saptandı. BOS direk mikroskobi bakısında 20 lökosit/mm ${ }^{3}$ ve bol eritrosit görüldü. Yapılan incelemede BOS'ta EBV DNA (+) olarak saptandı. Olgu izleminde kardiyak arrest sonucu ex oldu.

\section{Tartışma}

Santral sinir sistemi viral enfeksiyonları klinikte nadir görülmemekle beraber insidansları net olarak belirlenmemiştir. Hastalar genellikle aseptik menenjit veya ensefalite özgü farklı şiddette semptomlar gösterir. Hastalığın sonucu da konağa ve organizmaya özgü faktörlere bağlı olarak benign bir klinik tablodan ölüm ile sonuçlanabilecek ciddi nörolojik semptomların geliştiği ansefalite kadar farklılık gösterebilir. Birçok olgunun etiyolojisi bilinmemekle birlikte özellikle moleküler tekniklerin gelişimi ile viral etkenlerin saptanmasında artış olmuştur. Ansefalit, menenjit veya myelit tanılı 3231 hasta örneğinde viral etkenlerin tarandığı bir çalışmada 320 olguda (\%9.9) kesin bir viral etken saptanmıştır. En sık saptanan etkenler VZV, HSV, enterovirüs ve influenza A olarak belirlenmiştir (15). Başka bir retrospektif çalışmada 787 BOS örneğinde en sık saptanan virüsler HSV, enterovirüs ve EBV'dir (16). Yakın dönemde 1570 ensefalitli hasta üzerinde yapılan yedi yıllık retrospektif bir çalışmada olguların 248'inde (\%16) kesin veya olası bir etken saptanmıştır. 248 olgunun 170'inde viral etiyoloji doğrulanmıştır. En sık tanımlanan virüsler enterovirüs, HSV-1, VZV ve Batı Nil virüsüdür (17). Bizim çalışmamızda, BOS örnekleri viral etkenlerden EBV, CMV, enterovirüs ve HSV açısından incelenmiştir.

Tablo-2. Literatürdeki Çalışmalarda BOS'ta Saptanan Viral Etkenlerin Dağılımı.

\begin{tabular}{lccl}
\hline \multicolumn{1}{c}{ Yayın } & $\begin{array}{c}\text { Hasta } \\
\text { sayısı }\end{array}$ & $\begin{array}{c}\text { Viral etiyoloji } \\
\text { (sayı-yüzde) }\end{array}$ & \multicolumn{1}{c}{ En sık saptanan etkenler } \\
\hline Koskiniemi M et al. (2001) (15) & 3231 & $320(\% 9.9)$ & VZV, HSV, enterovirüs ve influenza A \\
\hline Davies NW et al. (2005) (16) & 787 & $97(\% 12)$ & HSV, enterovirüs ve EBV \\
\hline Glaser CA et al. (2006) (17) & 1570 & $170(\% 10.8)$ & Enterovirüs, HSV-1, VZV ve Batı Nil virüsü \\
\hline
\end{tabular}


Herpes simpleks ensefaliti sporadik fatal ensefalitin önde gelen nedenidir (10). HSV ensefalitinin etkili antiviral tedavisinin olması ve nükleik asit testlerinin yüksek duyarlılık ve özgüllüğü bu testlerin tanıda kullanılmasını önemli hale getirmektedir. Yıllık görülme insidansı milyonda 2,5-4 vaka şeklinde olup cinsiyet ve mevsimsel fark göstermemektedir (10). HSV'ye bağlı santral sinir sistemi enfeksiyonu ile ilgili Türkiye'de yapılan çalışmalarda oranın \%9,7-19 arasında saptandığı gözlenmektedir (18-20). Bu çalışmada, 198 BOS örneğinden ikisinde (\%1) HSV DNA (+) olarak saptanmıştır. Bunlardan biri MR bulguları ile desteklenen HSV ensefaliti olgusudur. Diğer olgu HSV'ye bağlı bir myelit olgusudur. HSV'ye bağlı myelit nadir görülmekle beraber daha çok asendan myelit, nekrotizan myelit veya myeloradikülit şeklinde olmaktadır. HSV'ye bağlı myelitin başlangıç semptomları bizim olgumuzdaki gibi alt ekstremitelerde duyu-motor bozukluklar ve üriner sistem problemleridir (21). Bu çalışmada belirlenen oran daha önceki çalışmalar ile karşılaştırıldığında oldukça düşüktür. Bunun nedenlerinden bazıları HSV DNA'nın saptanmasının zor olabileceği nörolojik semptomların başladıktan sonraki ilk 1-3 gün içerisinde örneğin yollanması veya hızla başlanan asiklovir tedavisi olabilir.

CMV enfeksiyonlarında nörolojik komplikasyonlar özellikle immünsupresif hastalarda sıklıkla gözlenir. Yine HIV (+) hastalarda CMV enfeksiyonunda, ensefalit, ventrikülit, akut poliradikülopati, myeloradikülopati, periferal nöropati gözlenebilmektedir. CMV'nin oluşturduğu santral sinir sistemi enfeksiyonlarında PCR'nin hızlı ve güvenilir bir araç olduğu gösterilmiştir $(22,23)$. CMV ensefaliti immünkompetan hastalarda genellikle primer enfeksiyon sırasında, immünsupresyonda ise daha çok reaktivasyonlar sırasında gerçekleşir (24). Bu çalışmada 46 olgudan birinde CMV DNA (+) saptanmıştır. Hastada herediter motor ve duysal nöropati olan Charcot Marie Tooth hastalığı bulunmaktadır. Hastanın geçmişinde immünsupresyona neden olabilecek bir durum bulunmamakla beraber kısa sürede hastanın kaybedilmiş olması ileri tetkiklerin yapılmasını önlemiştir.

EBV ile ilişkilendirilen nörolojik durumlar ensefalit, aseptik nörit, serebellar ataksi, myelittir $(25,26)$. Literatürde EBV ilişkili viral ensefalitlerin daha çok immünsuprese hastalarda görüldüğü bildirilmiştir. Bir diğer çalışmada, EBV DNA'nın immünsuprese hastaların BOS'unda genellikle başka mikrobiyolojik etkenler ile beraber bulunduğu saptanmıştır. Özellikle kök hücre alıcılarında EBV ile ilişkili ensefalit olguları bildirilmiştir (27). PCR bazı hastalarda özellikle HIV (+) hastalarda etken olarak EBV'nin saptanmasında önemli bir yere sahiptir. Bu çalışmada santral sinir sistemi enfeksiyonu düşünülen üç olgunun BOS örneğinde EBV DNA (+) saptanmıştır. $\mathrm{Bu}$ olgulardan biri ALL tanısı ile izlenen immünsupresif bir hastadır. Diğer iki hastada altta yatan ve immün baskılanmaya neden olabilecek hastalık saptanmamıştır. Hastalardan birinde 14 gün sonra alınan kan örneğinde anti-VCA IgM pozitifliği beraberinde antiVCA IgG pozitifliği ve anti-EBNA pozitifliği bulunmaktadır. $\mathrm{Bu}$ serolojik bulgular daha çok reaktivasyonu düşündürmektedir. Nadir görülmekle birlikte, immünkompetan hastalarda ensefalit mononüklozisin bir komplikasyonu olarak veya daha nadiren viral reaktivasyon ardından görülebilir. Serebellum olaya sıklıkla katılır. İmmünsuprese hastada tanısı oldukça güçtür ve tümör bulgularını taklit edebilir (24).

Enterovirüsler erişkinlerden çok çocuklarda enfeksiyona neden olur ve oluşturdukları hastalık spektrumu nonspesifik febril tablolardan, aseptik menenjit ve aseptik ensefalite kadar değişiklik gösterir. İmmün sistemi baskılanmış hastalarda kronik meningoensefalit de görülebilir. PCR'ın kullanımı enteroviral enfeksiyonların tanısında duyarlı ve özgüldür. Ancak yakın zamanda elde edilen kanıtlar, PCR'ın enterovirüs 71 tanısında sorun yaşanabileceğini düşündürmüştür. Bununla beraber meningoensefalite bağlı nörolojik semptomları olan hastalarda BOS'ta enterovirüs PCR hasta yönetiminde önemli bir yere sahiptir ve önerilmektedir $(28,29)$. Çalışmada enterovirüs RNA (+) saptanan bir olgu bulunmaktadır. Enterovirüsün aseptik menenjitlerin en önemli nedeni olduğu bilinmekle beraber Türkiye'de yapılan çalışmalarda enteroviral menenjit oranı \%0-63 arasında değişmektedir (30-34). $\mathrm{Bu}$ çalışmada az sayıda hastanın BOS örneğinde enterovirüs RNA bakılmış olması ve pediatrik hasta grubunun çok az olması gibi kısıtlılıklar bulunmaktadır.

Menenjit ve ensefalit, bakteriyel ve fungal nedenlerle de oluşmakla beraber dünyada virüsler 100000 olguda 6.34 ile santral sinir sistemi enfeksiyonlarının temel nedenidir (35). Tanı konusundaki sıkıntılar düşünülecek olursa bu sayının gerçek oranı yansıtmadığı açıktır (36). Bu çalışmada, klinik hekiminin bulguları ve ön tanısı doğrultusunda BOS'ta viral etken açısından nükleik asit testleri uygulanmış ve sonuçlar retrospektif olarak değerlendirilmiştir. BOS örneklerinin tümünde viral nükleik asit testlerinin tümünün bakılmamış olması çalışmanın bir sınırııı̆̆ıdır.

\section{Sonuç}

Viral santral sinir sistemi enfeksiyonlarının tanı ve tedavisi ile ilgili en önemli sorun, olası etiyolojik ajanların çeşitliliğidir. Hem RNA hem DNA virüsleri santral sinir sistemini enfekte ederek menenjit veya ensefalite neden olabilirken etiyolojik tanı olguların küçük bir kısmında koyulabilmektedir $(37,38)$. Bazı durumlarda mortalitesinin yüksek olması, hızlı ilerlemesi ve sekel bırakma olasılığı nedeni ile önemli bir hastalık grubu olduğunu akılda bulundurmak gereklidir. Moleküler yöntemlerin kullanımı ile viral etkenin tanımlanması, hasta yönetiminde önemli bir yere sahiptir. 


\section{Kaynaklar}

1. Smalling TW, Sefers SE, Li H, Tang YW. Molecular approaches to detecting herpes simplex virus and enteroviruses in the central nervous system. J Clin Microbiol 2002;40(7):2317-22.

2. Tülek N, Tanyel E. Santral sinir sistemi infeksiyonlarına genel bakış. In: Topçu AW, Söyletir G, Doğanay M (eds). İnfeksiyon Hastalıkları ve Mikrobiyolojisi Cilt 1, 3. Baskı. İstanbul: Nobel Tıp Kitapevleri; 2008:1375-88.

3. Tunkel AR, Scheld WM. Acute meningitis. In: Mandell GL, Bennett JE, Dolin R (eds). Mandell, Douglas and Bennett's Principles and Practice of Infectious Diseases, 6th ed. Philadelphia: Elsevier Churchill Livingstone; 2005:1083-126.

4. Modlin JF. Coxsackieviruses, echoviruses and newer enteroviruses. In: Mandell GL, Bennett JE, Dolin R (eds). Mandell, Douglas and Bennett's Principles and Practice of Infectious Diseases, 6th ed. Philadelphia: Elsevier Churchill Livingstone; 2005:2148-61.

5. Sawyer MH. Enterovirus infections: diagnosis and treatment. Pediatr Infect Dis J 1999;18(12):1033-9.

6. Rantakallio $P$, Leskinen $M$, von Wendt $L$. Incidence and prognosis of central nervous system infections in a birth cohort of 12.000 children. Scand J Infect Dis 1986;18(4):287-94.

7. Cherry JD, Nielsen KA. Aseptic meningitis and viral meningitis. In: Feigin RD, Cherry JD, Demler GJ, Kaplan SD (eds). Textbook of Pediatric Infectious Diseases, 5th ed. Philadelphia: Saunders; 2004:497-505.

8. Gershon AA. Mumps. In: Gershon AA, Hotez PJ, Katz SL (eds). Krugman's Infectious Diseases of Children. 11th ed. Philadelphia: Mosby; 2004:391-401.

9. Rotbart HA. Aseptic and viral meningitis. In: Long SS, Pickering LK, Prober CG (eds). Principles and Practice of Pediatric Infectious Diseases. 2nd ed. New York: Churchill Livingstone; 2003:284-91.

10.Tyler KL. Herpes simplex virus infections of the central nervous system: Encephalitis and meningitis, including Mollaret's. Herpes 2004;11(Suppl 2):A57-64.

11.Arısoy ES, Demmier GJ, Thakar S, Doerr C. Meningitis due to parainfluenza virus type 3: Report of two cases and review. Clin Infect Dis 1993;17(6):995-7.

12. Okumura A, Ichikawa T. Aseptic meningitis caused by human parvovirus B19. Arch Dis Child 1993;68(6):784-5.

13.Sayıner A. Viral santral sinir sistemi infeksiyonlarında tanı. ANKEM Derg 2005;19(2):129-44.

14.Griffin DE. Encephalitis, myelitis and neuritis. In: Mandell LG, Bennet JE, Dolin R (eds). Principles and Practice of Infectious Diseases. 6th ed. Philadelphia: Elsevier; 2005:1143-50.

15. Koskiniemi M, Rantalaiho T, Piiparinen $\mathrm{H}$ et al. Infections of the central nervous system of suspected viral origin: A collaborative study from Finland. J Neurovirol 2001;7(5):400-8.

16.Davies NW, Brown LJ, Gonde J, et al. Factors influencing PCR detection of viruses in cerebrospinal fluid of patients with suspected CNS infections. J Neurol Neurosurg Psychiatry 2005;76(1):82-7.

17.Glaser CA, Honarmand S, Anderson LJ, et al. Beyond viruses: Clinical profiles and etiologies associated with encephalitis. Clinical Infectious Diseases 2006;43(12):1565-77.

18.Sayiner A, Oktem M, Ergani A, Ergon C, Kurul S, Abacioglu YH. Detection of herpes simplex virus DNA and enterovirus RNA in cerebrospinal fluid using PCR and microplate or strip hybridization assay. Clinical Microbiology and Infection 2003;9(Suppl 1):410-9.

19.Zeytinoğlu A, Altuğlu I, Sayıner A ve ark. Herpes ensefalitinin beyin omurilik sıvısı örneklerinden polimeraz zincir reaksiyonu ile tanısı. Flora İnfeksiyon Hastalıkları ve Klinik Mikrobiyoloji Dergisi 2000; 5(3):179-82.

20. Altuglu I, Zeytinoglu A, Sirin H, Yuceyar N, Erensoy S. Comparison of different polymerase chain reaction methods for detection of herpes simplex virus types 1 and 2 encephalitis. Eur $J$ Clin Microbiol Infect Dis 2006;25(10):669-71.

21. Nakajima $\mathrm{H}$, Shoji $\mathrm{H}$. Herpes simplex myelitis: Differences in clinical manifestations between herpes simplex virus type 1 and type 2. Available from: http://www.intechopen.com

22. Cinque $\mathrm{P}$, Cleator GM, Weber T, et al. Diagnosis and clinical management of neurological disorders caused by cytomegalovirus in AIDS patients European Union concerted action on virus meningitis and encephalitis. J Neurovirol 1998;4(1):120-32.

23. Ginocchio CC. Laboratory diagnosis of human cytomegalovirus (HCMV) central nervous system disease in AIDS patients. Int $J$ Antimicrob Agents 2000;16(4):447-53.

24.Stahl JP, Mailles A, Dacheux L, Morand P. Epidemiology of viral encephalitis in 2011. Med Mal Infect 2011;41(9):453-64.

25.DeBiasi RL, Tyler KL. Molecular methods for diagnosis of viral encephalitis. Clin Microbiol Rev 2004;17(4):903-25.

26. Majid A, Galetta SL, Sweeney CJ et al. Epstein-Barr virus myeloradiculitis and encephalomyeloradiculitis. Brain 2002;125(Pt 1):159-65.

27.Martelius T, Lappalainen M, Palomäki M, Anttila VJ. Clinical characteristics of patients with Epstein Barr virus in cerebrospinal fluid. BMC Infect Dis 2011;11(2):281-5.

28.Big C, Reineck LA, Aronoff DM. Viral infections of the central nervous system: A case-based review. Clin Med Res 2009;7(4):142-6.

29. Ramers C, Billman G, Hartin M, Ho S, Sawyer MH. Impact of a diagnostic cerebrospinal fluid enterovirus polymerase chain reaction test on patient management. JAMA 2000;283(20):2680-5.

30.Guney C, Ozkaya E, Yapar M, Gumus I, Kubar A, Dogancı L. Laboratory diagnosis of enteroviral infections of the central nervous system by using a nested RT-polymerase chain reactin (PCR) assay. Diagn Micr Infec Dis 2003;47(4):557-62.

31.Özkaya E, Uysal G, Atak T, Alkan M. 2001-2004 yılları arasında aseptik menenjit ön tanılı pediatrik olgulardan izole edilen enterovirüs serotiplerinin dağılımı. Mikrobiyol Bült 2005;39(1):43-51.

32. Karakadıoğlu S. Aseptik menenjit ve kardit etiyolojisinde enteroviruslerin chip tekniği (microarray) ile araştırılması. Uzmanlık tezi; Manisa 2007.

33.Deniz E. Aseptik menenjitli hastaların bos örneklerinde enterovirüs ve herpesvirüslerin hücre kültürü ve PCR yöntemleri ile araştıııması. Uzmanlık tezi; Kayseri 2006.

34.Kılıç I, Altuğlu I, Ciçek C ve ark. Identification of enteroviruses from central nervous system infections by RT-PCR and cell culture methods. Mikrobiyol Bul 2011;45(3):468-77. 
35.Jmor F, Emsley HC, Fischer M, Solomon T, Lewthwaite P. The incidence of acute encephalitis syndrome in Western industrialised and tropical countries. Virol J 2008;30(5):134-7.

36.Sejvar JJ. The evolving epidemiology of viral encephalitis. Curr Opin Neurol 2006;19(4): 350-7.

37.Tunkel AR, Glaser CA, Bloch KC, et al. The management of encephalitis: clinical practice guidelines by the Infectious Disease Society of America. Clin Infect Dis 2008;47(3):303-27.

38.Stahl JP, Mailles A, Vaillant V, Floret D. Acute infectious encephalitis and pathogens coming from animals. Medicina (Kaunas) 2008;44(11):821-6. 